\title{
A CHEMICAL AND HISTOCHEMICAL STUDY OF ACID PHOSPHATASE IN THE EPIDIDYMIS OF NORMAL, CASTRATE AND HORMONE REPLACED CASTRATE MICE ${ }^{1}$
}

\author{
JOHN M. ALLEN AND JUDITH J. SLATER \\ Department of Zoology, The University of Michigan, \\ Ann Arbor, Michigan \\ TEN FIGURES
}

Chemical and histochemical studies have demonstrated a striking complexity of organization in the epididymal canal of the mouse (Allen and Slater, '57). Alkaline phosphatase and aliesterase were present in significantly different amounts (or activities) in the head, and body and tail of the epididymis. Marked lobal variation was observed in the activities of these enzymes in the head segments of the epididymal duct. Nonciliated, club-shaped cells, enzymatically distinct from other cells were demonstrated in head lobe 3 . These results appeared to warrant investigation of other enzymes in this tissue. The present paper deals with the behavior of chemically and histochemically determined acid phosphatase in the epididymis of intact, castrate and hormone replaced castrate mice.

\section{MATERIALS AND METHODS}

All work was carried out on epididymides from 90-180 day old BALB/c Jax male mice. Animals for castration

${ }^{1}$ This research has been supported by grants from the National Cancer Institute of the U. S. Public Health Service (C-2751-C) and by an American Cancer Society Institutional Grant to the University of Michigan. The microtome cryostat and Beckman Model DU Spectrophotometer employed in this study were purchased with funds provided by the Michigan Alumni Faculty Equipment Fund, H. H. Rackham School of Graduate Studies, the University of Michigan. 
studies were utilized 60 days following operation. Animals for hormone replacement studies were implanted subcutaneously with a single pellet containing $1 \mathrm{mg}$ testosterone propionate and $9 \mathrm{mg}$ cholesterol 30 days after orchidectomy. These animals were utilized 30 days following implantation of the hormone pellets.

Acid phosphatase was determined histochemically using the method proposed by Gomori ('52). Preparation of the substrate solution was modified as follows; $120 \mathrm{mg} \mathrm{Pb}\left(\mathrm{NO}_{3}\right)_{2}$ were dissolved in $100 \mathrm{ml} 0.05 \mathrm{M}$ acetate buffer of $\mathrm{pH} 4.7$, next $300 \mathrm{mg}$ of sodium- $\beta$-glycerophosphate were added and the substrate mixture was incubated at $37^{\circ} \mathrm{C}$ for one to two hours, filtered and used immediately. Prior to incubation of tissue sections the $\mathrm{pH}$ of the substrate was adjusted to exactly 4.7 with a glass electrode. Substrate prepared in this manner showed little precipitation and gave consistent results. Tissues to be studied for the localization of acid phosphatase were sectioned at $10 \mu$ in a microtome cryostat at $-20^{\circ} \mathrm{C}$. Prior to sectioning, these tissues were quick frozen by placing them in a test tube immersed in a slush of dry ice and acetone. Sections were mounted on glass slides with no adhesive. Chemical fixatives were not employed. Before immersion in the substrate solution sections were removed from the cryostat and allowed to dry at room temperature for 5-10 minutes. Optimum incubation time for these sections was one hour at $37^{\circ} \mathrm{C}$. Sections treated with water at $90^{\circ} \mathrm{C}$ for 10 minutes or sections incubated in substrate solutions containing $0.005 \mathrm{M}$ sodium fluoride served as controls. These control sections showed no histochemical reaction.

Acid phosphatase was determined quantitatively using an adaptation of the method proposed by Shinowara et al. ('42) and substituting N-phenyl-p-phenylenediamine hydrochloride (Dryer et al., '57) for the original reducing agent. Enzyme activity was determined using crude tissue homogenates suspended in $0.9 \% \mathrm{NaCl}$. The activity of these homogenates was determined immediately after preparation. The substrate 
solution was adjusted to $\mathrm{pH} 4.7$ using a glass electrode. One part of crude tissue homogenate was incubated with 9 parts of substrate solution at $37^{\circ} \mathrm{C}$ for three hours. After incubation two parts of $30 \%$ trichloroacetic acid were added to each tube and the tubes were centrifuged at $2500 \mathrm{G}$ for 10 minutes. One part molybdate solution, three parts of the above supernatant solution, and 6 parts of N-phenyl-p-phenylenediamine hydrochloride reagent were mixed in this order and color was allowed to develop for 10 minutes. Color was measured spectrophotometrically at $700 \mathrm{~m} \mu$ using a Coleman Model 6A spectrophotometer (intact animals) or at $350 \mathrm{m \mu}$ using a Beckman Model DU spectrophotometer (castrate and hormone replaced castrate animals). Low acid phosphatase activity in tissues from castrate and hormone replaced castrate animals made it necessary to take advantage of the greater optical density of the color reaction at $350 \mathrm{~m} \mu$. Identical results were obtained when homogenates of normal control tissues were measured under the two spectrophotometric conditions. Epididymides used for quantitative determination of acid phosphatase activity were divided as follows: (a) samples of proximal portions contained the head and anterior half of the body of the epididymis and (b) samples of distal portions contained the posterior half of the body and the tail of the epididymis. Total nitrogen was determined by direct Nesslerization (Levy, '36). Color developed was measured at $460 \mathrm{~m} \mu$ using a Coleman Model $6 \mathrm{~A}$ spectrophotometer. Enzyme activity was expressed as micrograms of phosphorus liberated per hour per milligram of total nitrogen in the homogenate used for analysis. Data were analyzed using standard statistical methods.

\section{HISTOCHEMICAL RESULTS}

\section{Normal males}

Histochemically determined acid phosphatase, when present, was concentrated almost exclusively in the Golgi region of ciliated epithelial cells (figs. 1 and 2). However, the nonciliated epithelial cells found primarily in head lobe 3 (Allen 
and Slater, '57) showed not only a concentration of the enzyme in the Golgi region but, in addition, appreciable levels of activity in the general cytoplasm. Isolated epithelial cells found in the lower body and in the tail regions of the epididymal canal showed a homogeneous distribution of acid phosphatase throughout the cytoplasm (see below). Under the conditions employed in this study a nuclear localization of acid phosphatase was never observed. Basal cells and connective tissue cells contained no demonstrable acid phosphatase activity.

Marked regional differences in the activity of histochemically determined acid phosphatase were observed. The enzyme appeared to be absent from the epithelial cells found in head lobe 1 (fig. 3). Moderate acid phosphatase activity was observed in head lobe 2 (fig. 3). Enzyme activity dropped to low levels in the ciliated cells of head lobe 3, but the non-ciliated epithelial cells of this lobe showed an intense reaction (fig. 4). Increasing acid phosphatase activity was observed in head lobes 4,5 , and 6 (fig. 5), activity in the latter region being comparable to or higher than that observed in head lobe 2 (fig. 3). Enzyme activity fell precipitously in head lobe 7 and the majority of the cells in this region showed no demonstrable activity (fig. 6). Isolated cells or groups of cells, however, showed activity comparable to that observed in the immediately preceding segments.

Histochemically demonstrable acid phosphatase activity was absent from the majority of epithelial cells of the body and tail segments of the epididymal canal. However, isolated cells or groups of cells in the lower body and all tail portions of the epididymal canal possessed intense acid phosphatase activity (fig. 7). These cells appeared to be morphologically identical to neighboring cells of low activity.

\section{Castrate males}

Histochemically determined acid phosphatase in epididymides from castrate animals showed activity comparable to that seen in normal control animals (fig. 8). The atrophic condi- 
tion of these tissues made the determination of lobal changes in enzyme activity in head segments difficult. The lobal differences in acid phosphatase activity observed in head segments from normal control animals, however, appeared to be abolished by castration. Also, the intensely active cells in head lobe 3 and in the distal segments of the epididymal canal were no longer visible. The enzyme was concentrated in the region of the cell apex but low to moderate levels of activity were present in the general cytoplasm.

\section{Testosterone propionate treated castrate males}

The distribution and activity of histochemically determined acid phosphatase in sections of epididymides from testosterone propionate-replaced, orchidectomized animals were indistinguishable from those of normal animals save in two respects. (a) In all head segments (except lobe 1) large numbers of isolated cells of intense activity were present (fig. 9). These cells were similar to those non-ciliated clubshaped cells found primarily in head lobe 3 of intact animals. The enzyme was localized in the apex of the cell in the region of the Golgi body. (b) In the body and tail segments of the epididymal canal a marked increase in the number of cells of intense activity was observed (fig. 10). These cells were morphologically similar to those observed in these regions in normal control animals. The enzyme was homogeneously distributed throughout the cytoplasm.

\section{QUANTITATIVE CHEMICAL RESULTS}

Chemical determinations of acid phosphatase activity (table 1) confirmed and extended the above histochemical observations. Significantly greater specific activity of acid phosphatase was present in proximal portions than in distal portions of epididymides from normal control animals $(0.02<$ $\mathrm{P}<0.05)$ and hormone replaced castrate animals $(0.02<$ $\mathrm{P}<0.05)$. The quantitative difference between proximal and distal portions was abolished by orchidectomy $(P=0.5)$. 
Castration significantly lowered the specific activity of acid phosphatase in proximal portions $(\mathrm{P}<0.001)$ and in distal portions $(\mathrm{P}<0.001)$ of epididymides when compared to normal control tissues. Testosterone propionate treatment of castrate animals significantly raised the activity of acid phosphatase in proximal portions of epididymides over castrate levels $(0.02<\mathrm{P}<0.05)$. Proximal portions of epididymides from normal control animals, however, showed significantly greater enzyme activity than did proximal portions

TABLE 1

Mean specific activity ${ }^{1}$ of acid phosphatase in mouse epididymis

\begin{tabular}{lccl}
\hline & INTACT & $\begin{array}{c}\text { CASTRATE } \\
60 \mathrm{DAYS}\end{array}$ & $\begin{array}{c}\text { CASTRATE 30 DAYS } \\
\text { PLUS TESTOSTERONE } \\
\text { PROPIONATE 30 DAYS }\end{array}$ \\
\hline Proximal segment & $1.939 \pm 0.371(15)$ & $1.158 \pm 0.346(13)$ & $1.415 \pm 0.176(10)$ \\
Distal segment & $1.604 \pm 0.382(13)$ & $1.057 \pm 0.356(11)$ & $1.219 \pm 0.197(7)$ \\
\hline
\end{tabular}

${ }^{1}$ Expressed as $\log$ ( $\mu \mathrm{g} \mathrm{P}$ liberated per hour per $\mathrm{mg}$ total $\mathrm{N}$ ) followed by standard deviation. Effective $\mathrm{N}$ for each experimental group follows in brackets.

of epididymides from testosterone propionate replaced castrate animals $(\mathrm{P}<0.001)$. Testosterone propionate treatment of castrate animals did not significantly increase the level of acid phosphatase activity in distal portions of epididymides over that found in distal portions of epididymides from castrate animals $(0.3>\mathrm{P}>0.2)$. Distal portions of epididymides from hormone treated castrate animals contained significantly less acid phosphatase activity than did equivalent samples from normal control animals $(0.02<\mathrm{P}<$ $0.05)$.

\section{DISCUSSION}

These results are compatible with the previous suggestion (Allen and Slater, '57) that the epididymal canal of the mouse possesses a high degree of biochemical differentiation along its length. As in the case of alkaline phosphatase and aliesterase, acid phosphatase showed marked lobal variation in the head portions of the epididymal canal. Also a clear differentiation between the head segments and the body and 
tail segments of the epididymal canal may be made on the basis of acid phosphatase activity. Nicander ('56) has demonstrated the existence of marked regional differentiation of both a morphological and a histochemical nature in the epididymis of the rabbit. Nicander's work and our own suggest that various portions of the epididymal canal may be involved in diverse physiological function. Although the exact nature of these physiological activities is unknown it seems likely that this tissue makes an important contribution to sperm maintenance. This contribution may be adapted to meet different (and as yet undemonstrated) metabolic requirements of immature sperm in the proximal portions of the epididymal canal and of more mature sperm in the distal portions of the canal.

The localization of acid phosphatase in the Golgi region of the epithelial cells of the epididymal canal is of interest. An association between histochemically determined acid phosphatase and the Golgi material has been reported in such diverse tissues as mouse ventral prostate (Brandes and Bourne, '54), duodenal epithelium of several species (Deane and Dempsey, '45), and the epithelial cells of pregnant uterus from the cat and sow (Deane and Dempsey, '45). Cell fractionation studies have demonstrated appreciable concentrations of this enzyme in the Golgi fraction of rat epididymides (Schneider and Kuff, '54). Evidence from these sources and from this laboratory (Allen and Slater, '57) indicate that the Golgi material, like the mitochondria (Schneider, '53), is biochemically heterogeneous.

The physiological role of acid phosphatase in epididymal cells of the mouse, as in other localities, is unknown. Biochemical and cytochemical studies have shown phosphatases of the acid variety to have activity against a number of metabolically important phosphate esters (Sumner and Somers, '53; Bourne, '54). Deane and Dempsey ('45) feel that Golgiassociated phosphatases are destined to become secretory products and are not concerned with cellular metabolism. 
Acid phosphatase in the epididymis of the mouse appears to be under the control of androgenic hormones. It will be recalled that histochemical determinations did not indicate lowered activity of this enzyme following orchidectomy. Quantitative determination of specific activity, however, indicated that significant depression of activity followed orchidectomy. On the other hand, doses of testosterone propionate sufficient to restore cytological integrity in the epididymis of castrate animals caused a significant increase in specific activity only in proximal portions of this tissue. The apparent contradiction in these results may be resolved. The presence of spermatozoa in homogenates of epididymides from intact control animals probably accounts for the highly significant drop in acid phosphatase activity seen when such tissues are compared to those from castrate animals. The presence of phosphatases in sperm has been demonstrated both cytochemically (Friedlaender and Fraser, '52) and chemically (Mann, '45). Samples of distal portions of epididymides from hormone treated aninmals probably failed to show significant elevation of enzyme activity over castrate levels because of the inclusion of large numbers of cells of low activity in these regions. The most valid demonstration of the hormone dependency of this enzyme seems to reside in comparisons of data derived from castrate animals and testosterone propionate treated castrate animals. The failure of histochemical preparations to show depression of acid phosphatase activity in ciliated epithelial cells following orchidectomy may be an example of one pitfall encountered in the visual quantitation of dye deposits in tissue sections. The hormone independence observed histochemically is probably due to the concentration of a less active enzyme population into a smaller space with consequent maintenance of intensity of dye deposition. Gomori ('52) has discussed this type of histochemical artifact. Acid phosphatase activity in the non-ciliated cells of head lobe 3 and in those isolated cells found in the body and tail portions of the epididymal canal is clearly under the control of androgenic hormones. That these cells are not discernible in 
histochemical preparations of epididymides from castrate animals may be due both to a loss of acid phosphatase activity as well as to a reversion to a basic morphological type not distinguishable from other cells in the atrophied epithelium.

The presence of two cell types in the body and tail portions of the epididymal canal was indicated by the occurrence of intensely acid phosphatase positive cells in an otherwise histochemically negative epithelium. Previous work (Allen and Slater, '57) has demonstrated that certain cells or groups of cells in these same regions showed very low aliesterase activity in contrast to the intense reaction of the rest of the epithelium. It seems likely that these cells of low esterase activity are the same as those showing high acid phosphatase activity. Chessick ('53) has also demonstrated the presence of two cell types in the body and tail portions of mouse epididymides using Naphthol AS acetate as substrate.

The development of large numbers of intensely acid phosphatase positive cells in both the head and tail segments of the epididymal canal following treatment of castrate animals with pellets of testosterone propionate was surprising. The origin of these cells, the relation between those found in the head and those found in the body and tail portions of the epididymal canal, and the physiological functions of these cells are unknown. Failure to observe these transformations previously (Allen and Slater, '57) may be due to the fact that lower total hormone doses were employed in replacement studies.

\section{SUMMARY}

The distribution and specific activity of acid phosphatase in epididymides of normal, eastrate, and testosterone propionate-replaced castrate animals has been investigated.

1. Histochemically determined acid phosphatase was concentrated in the Golgi region of ciliated epithelial cells. The non-ciliated epithelial cells found in head lobe 3 also showed a concentration of the enzyme in the Golgi region. Isolated epithelial cells found in the body and tail segments of the epididymal canal showed a homogeneous distribution of the 
enzyme throughout the cytoplasm. Basal cells and connective tissue cells contained no acid phosphatase activity. A nuclear distribution of the enzyme was never observed.

2. Regional differences in the activity of acid phosphatase were observed. Head lobe 1 contained no acid phosphatase activity but moderate levels were observed in head lobe 2 . Ciliated epithelial cells of head lobe 3 showed low activity but the non-ciliated cells in this segment were intensely active. Moderate levels of activity were found in epithelial cells of lobes 4, 5, and 6. Abrupt depression of activity was observed in the cells of head lobe 7. The majority of cells found in the body and tail segments of the epididymal canal were negative but isolated epithelial cells showed intense activity.

3. Histochemical preparations showed no lowering of acid phosphatase activity following orchidectomy but quantitative determinations of specific activity indicated significant depression of activity following this treatment.

4. Testosterone propionate reversed the changes observed following orchidectomy.

\section{LITERATURE CITED}

Allen, J., ANd J. Slater 1957 A chemical and histochemical study of alkaline phosphatase and aliesterase in the epididymis of normal and castrate mice. Anat. Rec., 129: 255-273.

Bourne, G. 1954 Some chemical and biochemical aspects of the Golgi apparatus. J. R. Micr. Soc., 74: 180-187.

Brandes, D., AND G. Bourne 1955 The histochemistry of the prostate in normal and in castrated and hormone-treated mice and of prostatic homografts exposed to 20-methyl cholanthrene. Brit. J. Exp. Path., 35: $577-588$.

Cressick, R. 1953 Histochemical study of the distribution of esterases. J. Histochem. Cytochem., 1: 471-485.

Deane, H., AND E. DEMPser 1945 The localization of phosphatases in the Golgi region of intestinal and other epithelial cells. Anat. Rec., 93: $401-417$.

DRYer, R., A. TAMmes AND J. RouTH 1957 The determination of phosphorus and phosphatase with N-phenyl-p-phenylenediamine. J. Biol. Chem., 295: $177-183$.

Friedlatender, M., AND M. Fraser 1952 Cytochemical reactions of ram spermatozoa. Exp. Cell. Res., 3: 462-474.

Gomori, G. 1952 Microscopic Histochemistry. The University of Chicago Press, Chicago. Chap. V, 20-25 and Chap. VIII, 189-194. 
LEVY, M. 1936 Studies on enzymatic histochemistry. XVII. A micro Kjeldahl estimation. Compt. rend. trav. Carlsberg, Sér. chim., 21: 101-110.

Mann, T. 1945 Studies on the metabolism of semen. I. General aspects. Occurrence and distribution of cytochrome, certain enzymes and coenzymes. Biochem. J., 39: 451-458.

NICANDER, L. 1957 On the regional histology and cytochemistry of the ductus epididymidis in rabbits. Acta Morph. Neerlando-Scandinavica, 1: 99-118.

SCHNEIDER, W. 1953 Biochemical constitution of mammalian mitochondria. J. Histochem. Cytochem., 1: 212-233.

SCHNEIDER, W., AND E. KUFF 1954 On the isolation and some biochemical properties of the Golgi substance. Am. J. Anat., 94: 209-224.

Shinowara, G., L. Jones and H. Reinhart 1942 The estimation of serum inorganie phosphate and "acid" and "alkaline" phosphatase activity. J. Biol. Chem., 142: 921-933.

Sumner, J., AND G. Sommers 1953 Chemistry and Methods of Enzymes. Academic Press, Ine., New York. Chap. II, 90-92. 


\section{PLATE 1}

\section{EXPLANATION OF FIGURES}

1 Golgi apparatus in head of epididymis from normal intact mouse. DeFano silver preparation. $\times 360$.

2 Localization of acid phosphatase in lobe 5 of head of epididymis from normal intact mouse. Compare the distribution of precipitate in this figure with the position of the Golgi apparatus seen in figure $1 . \times 360$.

3 Distribution of acid phosphatase in head lobe 1 (top) and head lobe 2 (bottom) of epididymis from normal intact mouse. Little or no enzyme is present in lobe 1 but moderate levels of activity are to be seen in lobe 2 . $\times 120$.

4 Distribution of acid phosphatase in head lobe 3 of epididymis from normal intact mouse. The ciliated epithelial cells possess low activity but the nonciliated epithelial cells show an intense reaction. $\times 120$.

5 Distribution of acid phosphatase in head lobe 5 of epididymis from normal intact mouse. Enzyme activity is comparable to that seen in head lobe 2 (fig. 3 , bottom). $\times 120$.

6 Distribution of acid phosphatase in head lobe 7 of epididymis from normal intact mouse. Activity of the enzyme, when present, is comparable with that seen in head lobe 5 (fig. 5). Note, however, that portions of the epithelium show no enzyme activity (top and lower right). $\times 120$. 

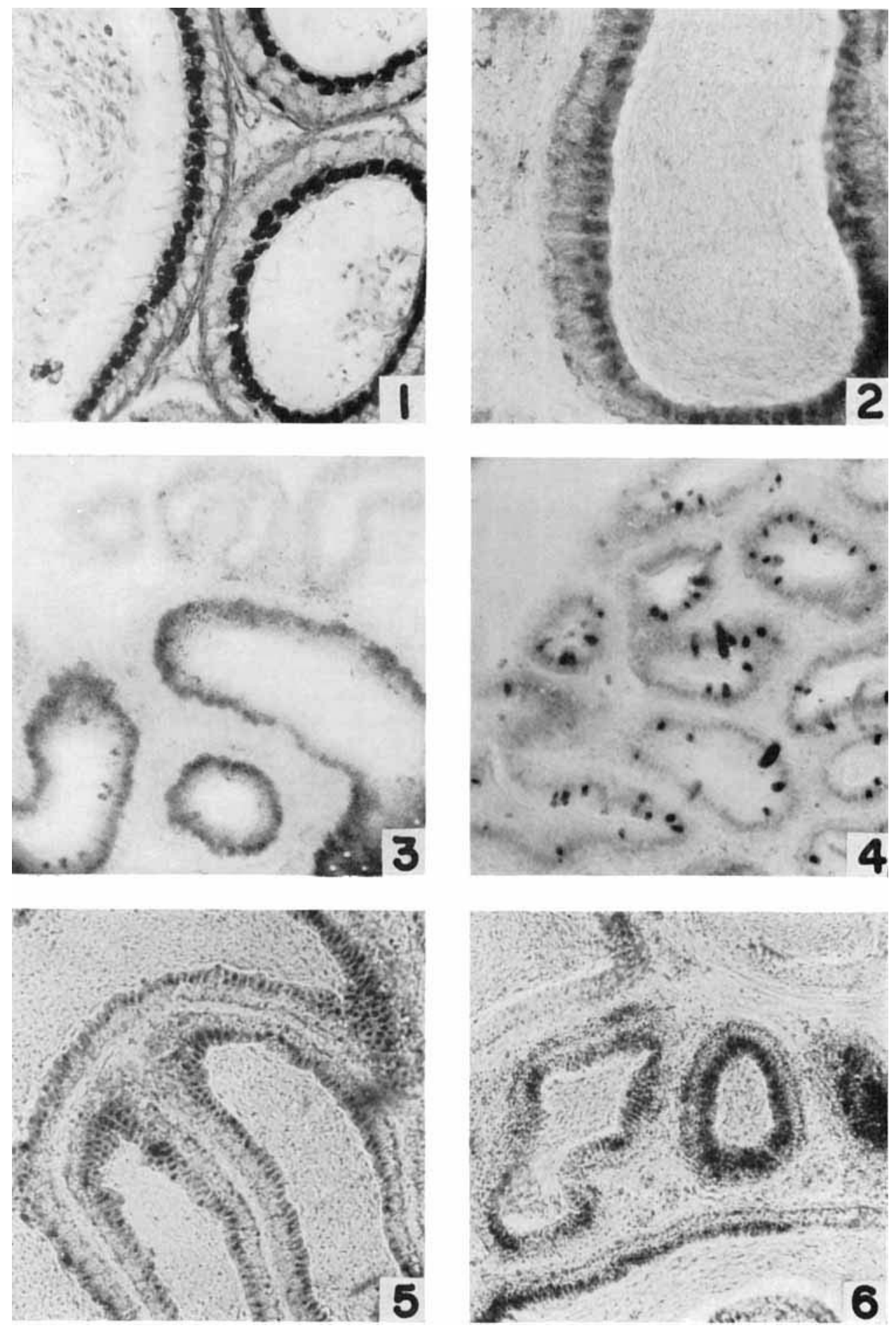
PIAATE 2

EXPLANATION OF FIGURES

7 Distribution of acid phosphatase in the body of epididymis from normal intact animal. The majority of epithelial cells show no activity but isolated cells give an intense reaction. A particularly large number of these isolated ceils of intense activity are included in this field. $\times 120$.

8 Distribution of acid phosphatase in the head of epididymis from animal which has been orchidectomized for 60 days. Enzyme activity is distributed throughout the general cytoplasm but appears to concentrate in the regions of the cell apex. Compare activity seen in this section with that seen in head lobe 2 (fig. 3, bottom) and head lobe 5 (fig. 5). $\times 120$.

9 Distribution of acid phosphatase in head lobe 4 (top) and hear lobe 5 (bottom) of epirlidymis from orchidectomized animal which hat been treateil with testosterone propionate. Note the presence of large numbers of cells showing intense acid plosphatase activity and compare with figure $4 . \times 120$.

10 Distribution of acid phosphatase in body of epididymis from orehidectomized animal which had been treated with testosterone propionate. Note the presence of large numbers of eells showing intense enzyme activity. $\times 120$. 

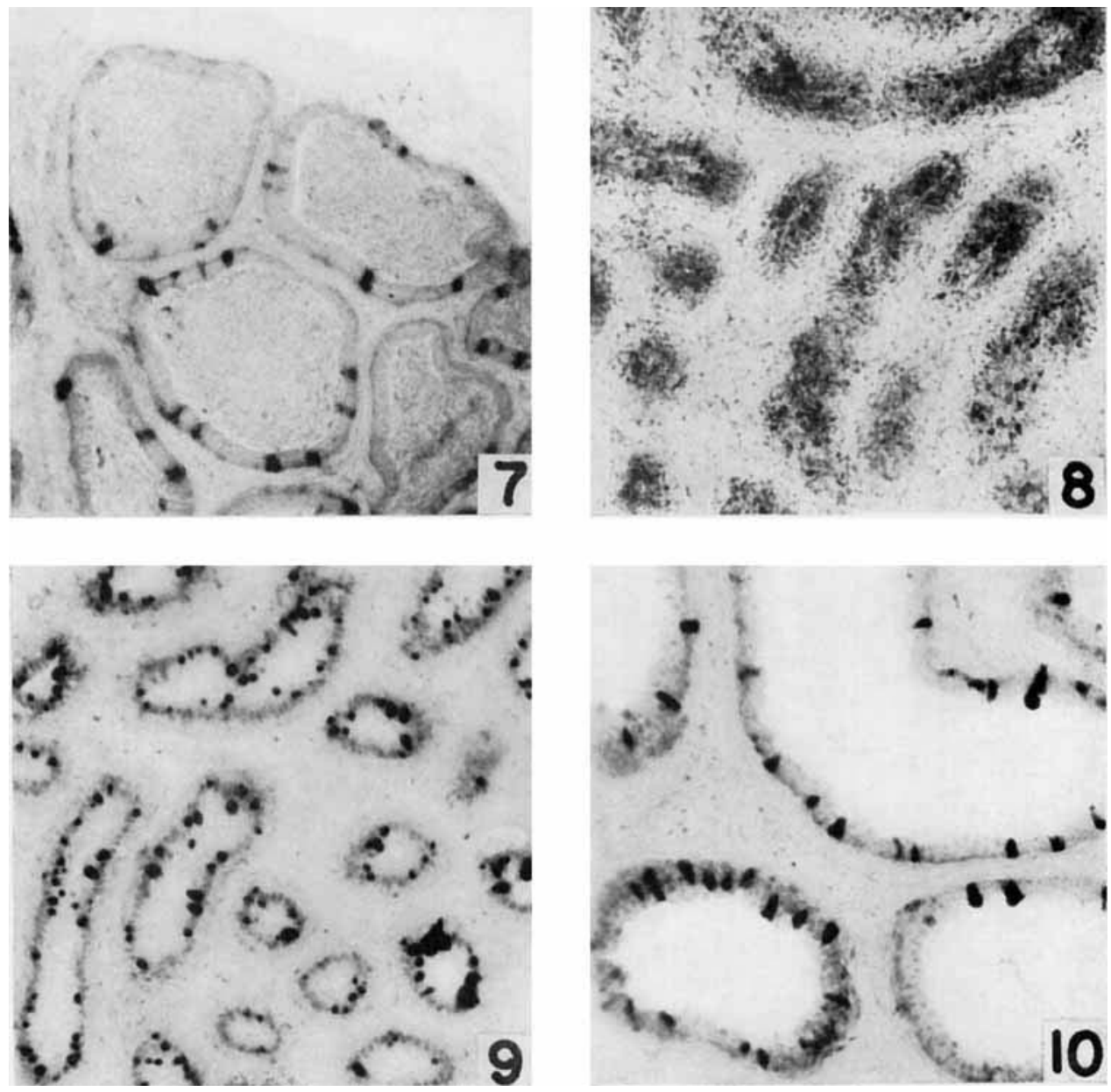